Leaf litter and the small-scale distribution of carabid beetles (Coleoptera, Carabidae) in the boreal forest

Koivula, M.

Blackwell

1999

Koivula, M. et al. 1999. Leaf litter and the small-scale distribution of carabid beetles (Coleoptera, Carabidae) in the boreal forest. Ecography 22: 424-435.

http://hdl.handle.net/1975/314

Downloaded from Helda, University of Helsinki institutional repository.

This is an electronic reprint of the original article.

This reprint may differ from the original in pagination and typographic detail.

Please cite the original version. 


\title{
Leaf litter and the small-scale distribution of carabid beetles (Coleoptera, Carabidae) in the boreal forest
}

\author{
Matti Koivula, Pekka Punttila, Yrjö Haila and Jari Niemelä
}

Koivula, M., Punttila, P., Haila, Y. and Niemelä, J. 1999. Leaf litter and the small-scale distribution of carabid beetles (Coleoptera, Carabidae) in the boreal forest - Ecography 22: 424-435.

\begin{abstract}
Management practices favoring conifers at the expense of deciduous tree species, and the eradication of deciduous trees, especially aspen Populus tremula, from managed forests have resulted in population declines in several species in Fennoscandia. In addition to species depending on decaying wood of deciduous trees, earlier evidence suggests that leaf litter, especially that of aspen, is favored by many carabid species. We ran a four-year experiment in order to compare carabid assemblages of unchanged forest floor with artificially created leaf-litter plots in central Finland. A total of 18 plots $(5 \mathrm{~m}$ in diameter) were established in three forest stands without aspen a few kilometers apart. Each stand had 3 litter plots (litter added) and 3 control plots. Pre-treatment samples were compared with those collected after litter addition.

The litter addition affected the carabid-assemblage structure by increasing the catches of some species and decreasing the catch of one species. The number of carabid species was similar in control and litter plots. The litter effect was smaller than variation among forest stands and year-to-year fluctuations. There was a strong temporal constancy among the plots: "rich" plots remained "rich" from year to year and similarly, "poor" plots remained "poor".

The significant influence of leaf litter on carabid abundance can be attributable to both abiotic factors (microenvironmental conditions, especially humidity and temperature), and biotic ones (changes in niche structure, improved food supply). Leaf litter seems to have an effect on carabid distribution patterns, and deciduous trees scattered among conifers are likely to be of importance on carabid fauna in boreal forests.
\end{abstract}

M. Koivula(mkoivula@,cc.helsinki.fi) and J. Niemelä,Dept of Ecology and Systematics, Div. of Population Biology, P.O.B. 17, FIN-00014 Univ. of Helsinki, Finland. - P. Punttila, Finnish Environment Inst., Nature and Land Use Division., P.O.B. 140, FIN-00251 Helsinki, Finland. - Y. Haila, Dept of Regional Studies and Environmental Policy, Univ. of Tampere, P.O.B. 607, FIN-33101 Tampere, Finland.

Boreal coniferous forests are heterogenous at several spatial scales (Haila et al. 1994a, Niemelä et al. 1996, Esseen et al. 1997). Within the forest stands, variation in fertility, humidity, microtopography, tree-species composition and heterogeneity of herb-layer vegetation result, in a microhabitat mosaic on the forest floor (Grüm 1971, Niemelä et al. 1992). This mosaic is reflected in the distribution of the forest-floor fauna. Often the microhabitats meeting the habitat requirements of individual species are patchily distributed and further, the suitable patches may be small and well separated from each other.

Human-induced changes in the pattern of natural patchiness, however, may possess a serious threat to the continued existence of several forest-inhabiting organisms. In large parts of the boreal region, both environmental heterogeneity and dynamics have changed as a consequence of intensive forest management (Hansson 1992, Esseen et al. 1997). Qualitatively, certain forest environments have become rare and it is thus impossi-

Accepted 27 February 1999

Copyright (C) ECOGRAPHY 1999

ISSN 0906-7590

Printed in Ireland - all rights reserved 
ble for species requiring these environments to survive and, quantitatively, spatial configuration of populations are affected (Haila and Kouki 1994). Fennoscandian examples of increased patchiness of certain microhabitat types include the destruction of spruce mires through efficient ditching, and eradication of deciduous trees (see e.g. Niemelä 1997, Esseen et al. 1997 and references therein).

Large aspens scattered among conifers are important for many threatened insects, molluses, lichens and polypores (Nuorteva 1987, Kuusinen 1994, Martikainen et al. 1994, Kotiranta and Niemelä 1996, Niemelä 1997, Esseen et al. 1997). In addition to the wood material as such, also the leaf-litter quality affects invertebrate distributions both directly and indirectly (Facelli and Pickett 1991). Distributional data indicate that especially aspen litter is important (e.g. Bossenbroek et al. 1977, Byers 1984, Niemelä 1990, 1997, Niemelä et al. 1992). Furthermore, experimental studies have shown that leaf litter is very important for microarthropods, slugs and snails, and spiders (Uetz 1979, Bultman and Uetz 1982, 1984, Seastedt et al. 1983, Reddy 1984, Boag 1985, Bird and Chatarpaul 1988).

Fennoscandian forest management has aimed at even aged and sized monocultures of conifers, that is, Norway spruce Picea abies and Scots pine Pinus sylvestris. As a consequence, aspen has been eradicated from the managed forests during recent decades because of its low economic value and its status as an intermediate host of the rust fungus Melampsora pinitorqua which attacks pine (e.g. Kärkkäinen 1981). Aspen is a prominent component in natural succession, and its removal alters the successions.

In this paper, we examine the effect of aspen-leaf litter on carabid-beetle assemblages by comparing artificial leaf-litter plots with unchanged coniferous forest floor. If the litter was found important for carabids and affected their distribution patterns, it is probable that the leaf-litter microhabitat is important for many other taxa, too. We used aspen-leaf litter because it is known to be important for many forest organisms, including threatened species of many taxa (Niemelä 1997), and partly because its leaves can easily be collected in sufficient amount.

We chose carabid beetles as a study object because they are ecologically diverse and reliable indicators of many environmental characteristics and qualitative changes of their environment (e.g. Langor et al. 1994). Furthermore, they are well known both taxonomically and ecologically. They are also easy to collect in large enough numbers with pitfall traps. Carabids may move up to hundreds of meters by foot under some circumstances (e.g. Mascanzoni and Wallin 1986, den Boer 1990), and species with wings and flight capability obviously much more. Thus, we assume that the scale we used in this study is appropriate for detecting habitat selection: carabids should be able to choose between aspen leaf-litter plots and unchanged forest floor, assuming that the leaf-litter microenvironment differs decisively from the surrounding forest floor.

In the present paper, we test whether 1) the abundances of individual species, 2) the number of species, and 3) the carabid-assemblage structure are affected by the leaf litter.

\section{Material and methods}

\section{The study design}

The study was done in Seitseminen National Park, Central Finland $\left(61^{\circ} 57^{\prime} \mathrm{N}, 23^{\circ} 24^{\prime} \mathrm{E}\right)$, on the border between southern and middle boreal zones (Ahti et al. 1968), in 1993-1996. We chose three spruce-dominated Myrtillus-type forest stands (Cajander 1949) with no or very few deciduous trees, but potentially suitable for aspen. The stands were several kilometers apart, previously managed forests (the age of the dominant spruces was $90-120 \mathrm{yr}$ ). The herb layer in the stands was dominated by Vaccinium myrtillus and Vaccinium vitisidaea dwarf scrubs, and the moss layer by Dicranum, Pleurozium and Hylocomium species. The size of each forest stand was several hectares. The surroundings were different types of usually younger, spruce- or pine-dominated forests.

In each forest stand, we established six circular study plots with a diameter of $5 \mathrm{~m}$ (Fig. 1). Distances between the plots were $25-30 \mathrm{~m}$. The minimum distance from the edge to another forest stand was $30 \mathrm{~m}$ to the nearest study plot.

The floristic composition of the plots was examined in 1993 prior to the adding of the litter by estimating the percentage cover of each of the moss and vascular plant species (scale $0-100 \%$ ). These data were used in evaluating the effect of vegetation variation on the carabid assemblages. Also the numbers of the wood ants (Formica rufa - group) were counted from the pitfall traps. We used these catches as environmental data for carabids because earlier work has shown that wood ants have a profound impact on the carabid fauna in boreal forests (e.g. Niemelä et al. 1992, Punttila 1994).

The effect of leaf-litter addition on carabid-beetle assemblages was studied using "Before-after with control-impact" - study design (BACI; Underwood 1991). Here, the impact was the leaf-litter addition. In 1993, we studied the before-treatment species composition of the stands (pre-treatment trapping). In late autumn 1993, litter was added to nine randomly selected plots (three in each of the three stands, Fig. 1). Just after the leaf-litter addition, the thickness of the litter layer was $5-10 \mathrm{~cm}$, the total amount of litter per plot being 250 1. In spring 1994, the thickness was $3-5 \mathrm{~cm}$. To mimic 
natural leaf fall we added 801 of litter to each litter plot in late autumn 1994 and 1995. This did not increase the thickness of the litter layer the following spring. The leaf litter began to decay quite rapidly in early summer 1994, approaching the characteristics of naturally fallen leaf litter. In 1995 and 1996, the decaying layers were very close to natural conditions: the upper layer consisted of dry leaves, and the deeper layer was well decayed with lots of fungi and even earthworms (Lumbricidae) (Koivula unpubl.).

The leaf-litter material was raked from roads near Seitseminen park area. We examined a random sample of 401 of this litter material leaf by leaf using loupes $(8 \times)$. In addition, we dried 201 of litter in Berlese-Tullgren funnels (see e.g. Southwood 1978). No carabid-beetle adults or larvae were found in the litter material. The majority of the invertebrates in the litter were mites (Acarina) (totally 345 individuals were found using both methods) and springtails (Collembola) (totally 83 individuals found).

The beetle samples were collected with pitfall traps (diameter $65 \mathrm{~mm}$, depth $88 \mathrm{~mm}$ ), partly filled with $30 \%$ ethylene glycol and detergent. The traps were covered with plexi roofs $(10 \times 10 \mathrm{~cm})$ to protect them from litter and rain. In order to increase the sampling efficiency, we used two perpendicular transparent polycarbonate panes $(100 \times 20 \mathrm{~cm}$ each $)$ to guide the beetles into the traps (Fig. 1). Three groups of four traps were used in each study plot, for a total of 216 traps $(3$ stands $\times 6$ plots $\times 12$ traps). The trapping period covered most of the growing season from mid-May through the beginning of September, and the traps were emptied once a month each year, 1993-1996.

\section{Data analyses}

Differences in beetle catches between the two plot types were examined by repeated measures analysis of variance (ANOVA). The data from 1993 ("before-impact") and from 1994, 1995 and 1996 ("after-impact") were transformed to individuals per 100 trapping days. Normal distribution of the data was achieved by $\log (\mathrm{x}+1)$ transformation. We used treatment (control/litter) and stand (the three forest stands) as factors. The data from 1993 were used as covariables in the ANOVA.

To study changes in the structure of carabid-beetle assemblages, we calculated Shannon-Wiener and Simpson diversity indices (e.g. Krebs 1989). The indices were calculated for each plot and the data were analysed with repeated measures ANOVA, using treatment and forest stand as factors, and data from 1993 as covariables.

Species richness among the stands, sampling years and the treatments was compared by calculating the expected number of species for standardized sample size in each plot type in each stand (pooled catches of the three plots of each treatment) for the samples from different years using rarefaction (Simberloff 1978).

We performed multivariate analyses (e.g. Jongman et al. 1995) using CANOCO 3.15 statistical software (ter Braak 1987 and update notes) in order to explore the floristic and faunistic variation among the plots and further, in order to relate the carabid-assemblage variation to the environmental variables. For the pre-treatment data (1993) of both vegetation and carabids, we applied a principal component analysis (PCA) to explore the floristic and carabid-assemblage variation among stands and plots. We included all the plant species in this analysis, and all carabid species occurring in more than one out of 18 samples samples. Further, we used redundancy analysis (RDA) to explore whether

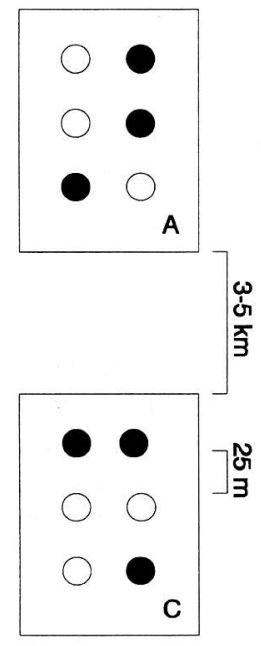

Fig. 1. The design.

\section{A, B, C - forest stands \\ - control plot \\ - litter plot}

plot diameter $5 \mathrm{~m}$ 12 pitfall traps

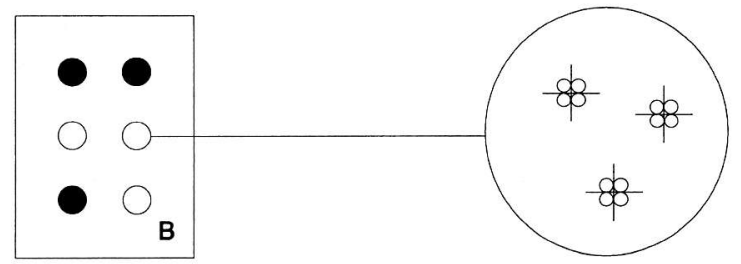


Table 1. The numbers of carabids caught before (1993) and after (1994-1996) the adding of the litter. C= control, L= litter plots. Nomenclature follows Lindroth $(1985,1986)$.

\begin{tabular}{|c|c|c|c|c|c|c|c|c|c|c|c|}
\hline \multirow[t]{2}{*}{ Species } & \multicolumn{2}{|c|}{1993} & \multicolumn{2}{|c|}{1994} & \multicolumn{2}{|c|}{1995} & \multicolumn{2}{|c|}{1996} & \multicolumn{2}{|c|}{ 1994-1996 } & \multirow[b]{2}{*}{ Total } \\
\hline & (C) & (L) & $\mathrm{C}$ & $\mathrm{L}$ & $\mathrm{C}$ & $\mathrm{L}$ & $\mathrm{C}$ & $\mathrm{L}$ & $\mathrm{C}$ & $\mathrm{L}$ & \\
\hline Calathus micropterus (Dft.) & 168 & 137 & 136 & 183 & 437 & 609 & 214 & 295 & 787 & 1087 & 2179 \\
\hline Pterostichus oblongopunctatus (F.) & 67 & 31 & 81 & 165 & 206 & 251 & 15 & 22 & 302 & 438 & 838 \\
\hline Notiophilus biguttatus (F.) & 25 & 40 & 34 & 47 & 34 & 32 & 60 & 52 & 128 & 131 & 324 \\
\hline Cychrus caraboides L. & 28 & 10 & 18 & 23 & 22 & 43 & 12 & 20 & 52 & 86 & 176 \\
\hline Carabus glabratus Payk. & 10 & 5 & 10 & 2 & 12 & 10 & 10 & 9 & 32 & 21 & 68 \\
\hline Amara brunnea (Gyll.) & 8 & 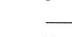 & 12 & 6 & 4 & 2 & 2 & 4 & 18 & 12 & 38 \\
\hline Carabus hortensis L. & 4 & 2 & 3 & 5 & 5 & 2 & 2 & 1 & 10 & 8 & 24 \\
\hline Leistus terminatus (Hellw. in Pz.) & 5 & 3 & - & 5 & 1 & 1 & 1 & 3 & 2 & 9 & 19 \\
\hline Dromius agilis $(\mathrm{F})$. & 1 & 4 & 1 & 2 & - & - & - & 1 & 1 & 3 & 9 \\
\hline Dromius fenestratus $(\mathrm{F})$. & 1 & - & - & 1 & - & - & - & - & - & 1 & 2 \\
\hline Pterostichus strenuus (Pz.) & 1 & - & - & - & - & 1 & - & - & - & 1 & 2 \\
\hline Carabus cancellatus Ill. & - & - & - & - & - & 1 & - & 1 & - & 2 & 2 \\
\hline Trechus secalis (Payk.) & 1 & - & - & - & - & - & - & - & - & - & 1 \\
\hline Trechus rubens (F.) & - & - & - & 1 & - & - & - & - & - & 1 & 1 \\
\hline Harpalus quadripunctatus Dej. & - & - & - & - & - & 1 & - & - & - & 1 & \\
\hline Pterostichus diligens (Sturm) & - & - & - & - & - & - & 1 & - & 1 & - & 1 \\
\hline No. of individuals & 319 & 232 & 295 & 440 & 721 & 953 & 317 & 408 & 1333 & 1801 & 3685 \\
\hline No. of species & 12 & 8 & 8 & 11 & 8 & 11 & 9 & 10 & 10 & 14 & 16 \\
\hline No. of trapping days & 109 & & 110 & & 106 & & 106 & & 322 & & 431 \\
\hline
\end{tabular}

the variation in the beetle assemblages was related to the floristic variation in the pre-treatment year 1993. We included $\log (x+1)$-transformed catch of wood ants in these environmental data. In this analysis, we included again only carabid species occurring in more than one plot. We applied forward selection of environmental variables by first examining which single variable explained the species variation best. The statistical significance of the relation between this variable and the species data was subsequently tested using Monte Carlo permutations $(\mathrm{n}=99$, permutations conditioned on blocks, i.e. the stands), and if the relation was found statistically significant (critical $p=0.05$ ) the variable was added into the explaining model. The selection was continued in the same manner by examining the relation between the remaining variables and the residual variation of the species data. Redundancy analysis was also utilized in testing the success of randomization in both floristic and carabid data of the pre-treatment year 1993. This was done by testing the effect of the "imaginary" environmental variable, litter treatment. In the above multivariate analyses, we applied centering by species and all the data were $\log (\mathrm{x}+1)$ transformed. The effect of stand (block) was partialled out by defining the stands as covariables.

We applied redundancy analysis also to test the effect of the litter treatment on the structure of the carabid assemblage in the BACI data (1993-1996). In this analysis, we included species which occurred in more than two samples (out of 72 samples). The effects of stand (block), year (time) and plot were partialled out by making them covariables. The litter treatment and the $\log (x+1)$-transformed catch of wood ants were used as environmental variables. These environmental variables were subjected to forward selection with sub- sequent testing using Monte Carlo permutations $(\mathrm{n}=$ 99 permutations for repeated measurements, conditioned on covariables: permutation classes were determined by block and time-BACI design in CANOCO). The data were centered by species and $\log (\mathrm{x}+1)$ transformed.

\section{Results}

\section{Species richness and abundance}

The carabid-beetle data consisted of 3685 individuals representing 16 species (Table 1). The most numerous species both in the litter and control plots were $\mathrm{Ca}$ lathus micropterus, Pterostichus oblongopunctatus, Notiophilus biguttatus and Cychrus caraboides. These four species made up $95.4 \%$ of the total catch. Three species were found exclusively in the litter-plot samples in 1994-1996, and one species exclusively in the controlplot samples in the same period.

The numbers of individuals caught varied a lot from year to year. The mean catches peaked in 1995 being clearly higher then than in the other years (Fig. 2). Pterostichus oblongopunctatus catch was lowest in 1996 (only 37 individuals) and highest in 1995 (457 individuals). Also $C$. micropterus and $C$. caraboides peaked in 1995, whereas $N$. biguttatus peaked one year later (Fig. 3 ). The total carabid catches were consistently much higher in stand $\mathrm{C}$ than in the other stands, and after the start of the experiment, consistently somewhat higher in the litter plots than in the control. Also the mean number of species caught was consistently higher in stand $\mathrm{C}$ than in the other stands throughout the study period, but no clear litter effect was detected. However, 
CARABID BEETLES

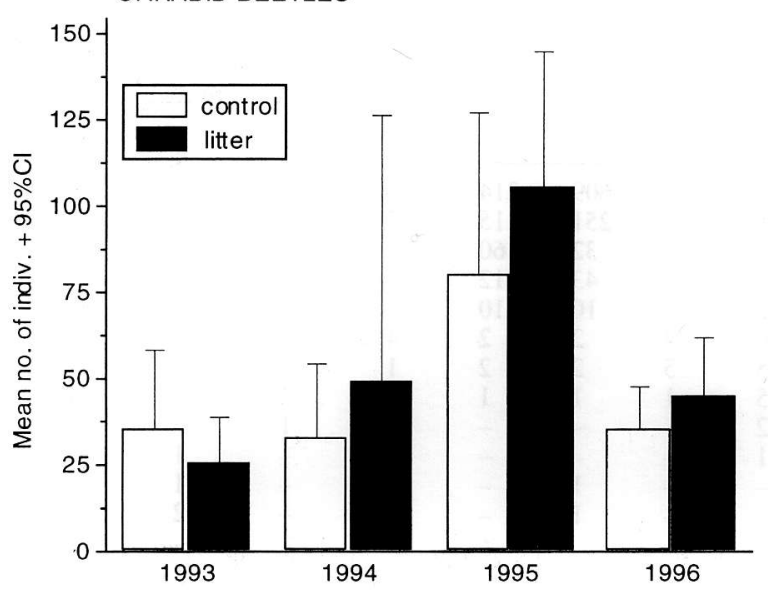

Fig. 2. The mean numbers of carabid beetles per 100 trapping days in control and litter plots in 1993-1996.

the mean number of species increased in the litter plots of all three stands and decreased similarly in respective control plots in the first year after litter was added. This was at least partly attributable to the increased sample size in litter plots. When the effect of sample size was removed using rarefaction, the expected number of species in samples standardized to 30 individuals was similar both among the stands and between the plot types. The only statistically significant differences were in the control plots of stand A: the expected number of species was higher in 1993 than in the subsequent years. The slight, albeit non-significant, decrease in the expected number of species in all stands and both plot types in 1995 was due to the peak in the catches of the few dominant species.
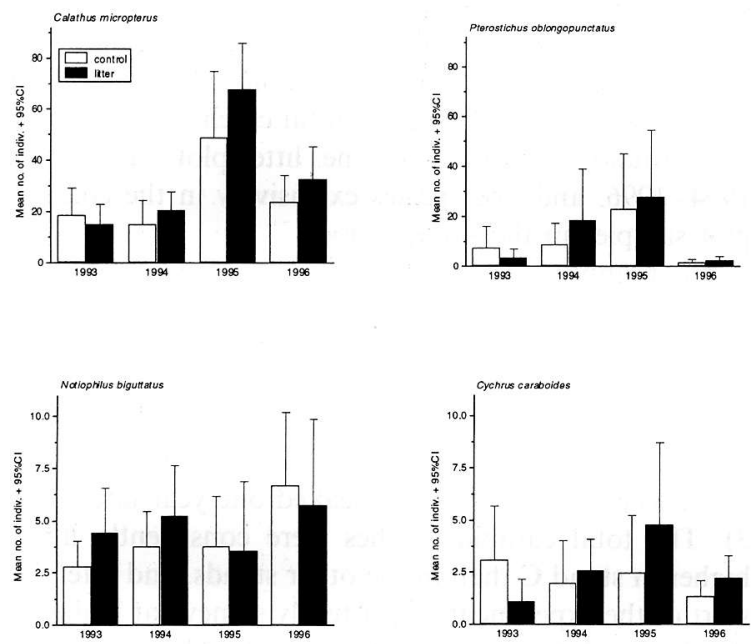

Fig. 3. The mean numbers of the four most numerous carabid species per 100 trapping days in 1993-1996. Note different scales in the two upper and the two lower figures in the vertical axes.

\section{Vegetation structure and carabid assemblages before the treatment}

Principal component analysis (PCA) of the vegetation data before the litter treatment indicated that the three stands were rather clearly separated from each other in the ordination space determined by the first two principal components. These floristic differences probably reflected subtle differences in the fertility and shading of the stands. The three stands represented typical variation within mature spruce dominated Myrtillus type, i.e. the moss layer was characterized by high cover of either Pleurozium (especially in the most well-lit stand B), Hylocomium (the most fertile stand C) or Dicranum (the most shady stand A) mosses. In the partial PCA, a large proportion of the floristic variation was explained by the covariables: $29.6 \%$ of the total floristic variation was among the stands. As among the stands, the gradients in fertility were detectable also among the plots within the stands in the ordination space, determined by the two first principal components. This ordination space contained $31.0 \%$ of the total floristic variation in addition to the proportion already explained by the covariables. A partial redundancy analysis testing the effect of the "imaginary" litter treatment verified our success in randomizing the litter treatment among the plots. There were no systematic floristic differences between the control and litter plots before the litter addition (Monte Carlo permutation test; $\mathrm{n}=99$ permutations conditioned on blocks, $\mathrm{F}=0.65, \mathrm{p}=0.800$ ).

Principal component analysis of the carabid data before the litter treatment revealed similar pattern as observed in the floristic data. The three stands were again separated from each other, the greatest difference being between the most fertile stand $\mathrm{C}$ and the two less fertile stands (the main gradient). Catches of most of the species were highest in the stand $\mathrm{C}$, whereas large catches of Notiophilus biguttatus in the stand B was the main cause of the slight separation of the somewhat more shady stand A from the more well-lit stand B (the secondary gradient). Partial PCA revealed that a very large proportion of variation was explained by the covariables: $59.7 \%$ of the total variation was among the stands, and the ordination space determined by the two first principal components explained an additional $22.0 \%$ of the total variation. The two main gradients of variation were characterized by the catch of $C$. caraboides (and also the catches of most other species) increasing to one direction, and by the catch of $N$. biguttatus increasing to the perpendicular direction (i.e. the main gradients were again rather similar as among the stands). As with the floristic data, partial redundancy analysis showed that the effect of the imaginary litter treatment was not significant (Monte Carlo permutation test; $\mathrm{n}=99$ permutations conditioned on blocks, $\mathrm{F}=1.62, \mathrm{p}=0.180$ ). This verified our success in randomizing the litter treatment among the plots also 
as regards to beetle assemblages. A partial RDA of the carabid data with forward selection of environmental variables revealed that the catch of the wood ants was the best variable to explain the beetle-species variation. Only one additional variable, the cover of the moss Hylocomium splendens, improved the fit between the model and the carabid data significantly. These two variables explained $11.9 \%$ of the total variation in the carabid data (in addition to the $59.7 \%$ explained by the covariables; above). The result showed that the catches of most species (the only exceptions were $N$. biguttatus and Amara brunnea) were negatively correlated with the catch of the wood ants (a gradient of increasing interference and/or predation). Additionally, the catches of especially $N$. biguttatus, Leistus terminatus and $C$. caraboides were positively correlated, and those of Carabus hortensis and C. micropterus negatively correlated with the cover of the moss Hylocomium (presumably a gradient of increasing fertility; gradient perpendicular to the wood-ant gradient).

\section{The effect of litter addition on carabids}

In the partial RDA of the BACI beetle data and the environmental variables (litter treatment and the woodant catch), the covariables again explained most of the variation among the samples (Fig. 4). Of the total variation, $77.4 \%$ was attributable to the covariables (stands alone $40.1 \%$, time alone $16.8 \%$ and plots alone $60.6 \%$ when the variation was decomposed for each covariable class). Litter treatment was found to have a significant effect on the beetle assemblage (no. of permutations $=99, \quad F=4.15, \quad p=0.010)$, whereas the wood-ant catch did not significantly explain the residual variation (no. of permutations $=99, F=1.32, p=$ 0.170 ). The litter treatment, however, explained only $1.7 \%$ of the total variation in the species data. The catches of especially C. caraboides, $L$. terminatus and $C$. micropterus correlated positively, and those of Dromius agilis and $N$. biguttatus negatively with the litter treatment (Fig. 4a). In addition to the litter-treatment effect, there was another rather clear gradient in the ordination of the samples in the ordination space determined by the two first RDA axes (the first axis was constrained to be the litter-treatment axis). This gradient was due to large catches of $N$. biguttatus in one direction and to large catches of $P$. oblongopunctatus and $C$. caraboides in approximately the opposite direction. The wood-ant catch did not contribute statistically significantly to the species variation, but when we fitted this variable as a passive environmental variable to the ordination, the direction of the wood-ant vector closely matched the direction of the gradient observed in the ordination of the samples. As the wood ants are territorial, it is likely that their effect on the carabids (see the RDA results for the pre-treatment data) is already
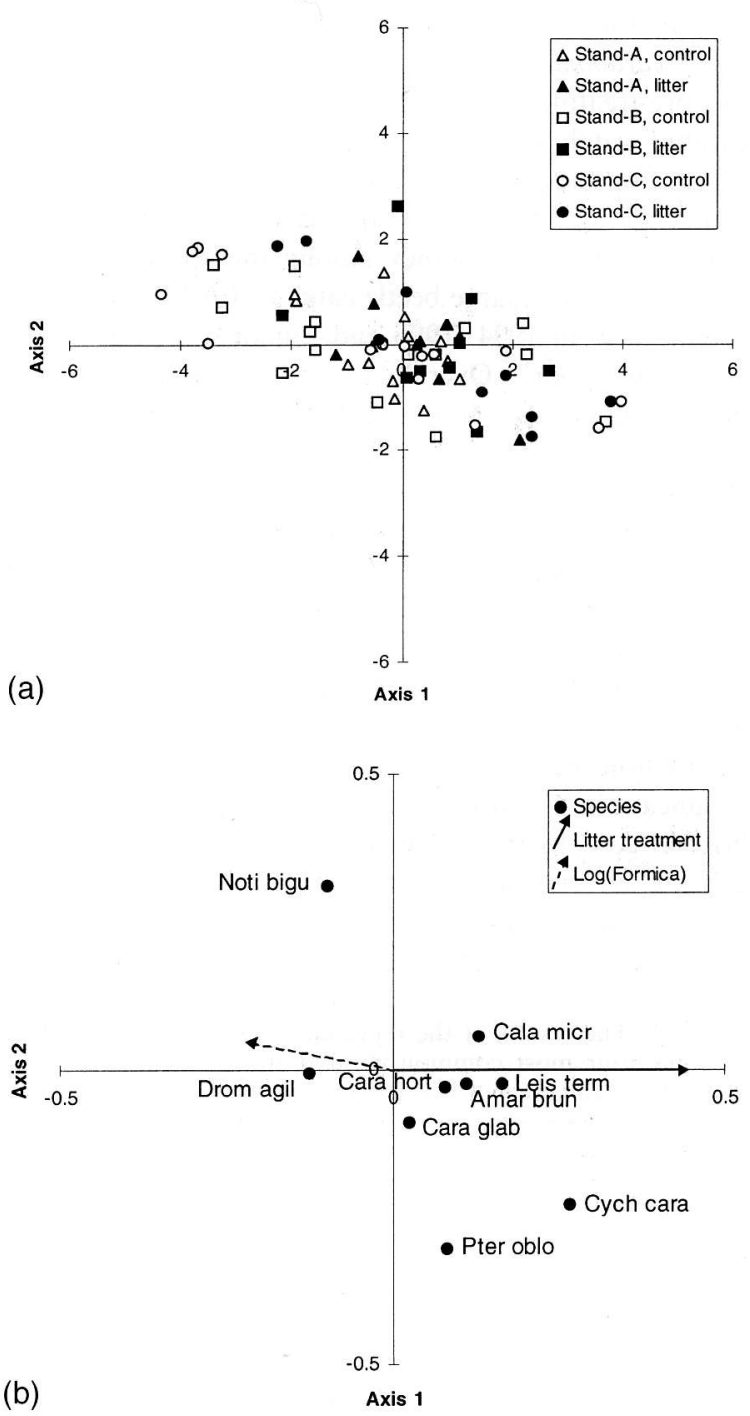

Fig. 4. a) Partial RDA ordination of the sampling plots according to their carabid samples 1993-1996 (the effects of stand, time and plot removed by using these as covariables). Key for the plot types and the stands is given in the figure. b) Partial RDA ordination of the carbid species in the sampling plots (parallel to a). The active environmental variable (litter treatment) and the passive one (wood-ant catch, $\log ($ Formica $)$ ) in the analysis are shown as arrows.

included in the covariables (plots) in the present RDA. The ordination also suggests that the litter addition may have lowered the catches of the wood ants, although such effect was not found significant in the ANOVA (see below).

The repeated measures ANOVA results for the wood ants, total carabid catches and the four most common carabid species are presented in Table 2. The effect of the factor Stand was statistically significant $C$. caraboides, the factor Treatment in the total carabid catches and three out of four most common species ( $C$. micropterus, $P$. oblongopunctatus and $C$. caraboides). 
The interaction term Stand $*$ Treatment was significant in $C$. caraboides catches, and the covariable (catch in the pre-treatment year 1993) in the wood ants, total carabid catch and three out of four most common carabid species, with $C$. caraboides an exception. The statistical significance of the covariable indicates a strong temporal constancy among the study plots, i.e. "rich" plots with large beetle catch in 1993 yielded large catches also in 1994-1996 and, similarly, "poor" plots remained "poor". Overall, the litter-plot samples harbored significantly more carabid beetles than the control-plot samples (Table 2, Fig. 2). Also C. micropterus, $P$. oblongopunctatus and $C$. caraboides were more numerous in the litter-plot samples as compared with the control-plot samples (Fig. 3). Notiophilus biguttatus did not respond to the litter addition, and there were no differences among the forest stands. Forest stand was an important factor in explaining the observed differences in the $C$. caraboides catches among the samples. Interaction between treatment and forest stand was significant in $C$. caraboides numbers, indicating that the litter effect was dependent on the stand. To study the possible effect of leaf-litter addition on carabid-assemblage structure, we calculated two different diversity indices for the study plots (Table 3). The Shannon-
Wiener diversity index values $\left(\mathrm{H}^{\prime}\right)$ varied between 0.25 and 1.37 in 1993, and between 0.22 and 1.53 in 1994 1996 among the plots. The mean $\mathrm{H}^{\prime}$ values in control plots were the same in 1993 and in 1994-1996 (0.91). In the litter plots, the values were 0.96 and 0.92 , respectively. The Simpson's evenness index values (D) varied between 0.10 and 0.68 in 1993, and between 0.08 and 0.73 in 1994-1996. In 1993, the mean values of $D$ were 0.49 in control and 0.48 in litter plots. After the leaf-litter addition (i.e. 1994-1996), the mean values were 0.48 and 0.47 , respectively. Thus, there were no treatment effects on the values of the diversity and evenness indices. The forest stand $\mathrm{C}$ had higher values of Simpson's evenness indices than the other stands, indicating that the proportion of "numerous" species was higher than in the two other study forest stands. Thus, the leaf-litter addition seemed to have no effect on the carabid-assemblage structure of the studied forest stands.

\section{Discussion}

Our results indicated that 1) both the total catches of carabid beetles and the catches of three out of four

Table 2. The results of the repeated measures ANOVA (F) for the total catch of wood ants (Formica rufa - group), carabids and the four most common carabid species. Stand = forest stand (A, B, C), Treatment (control, litter) and N1993=no. of individuals caught in 1993 (covariate).

\begin{tabular}{|c|c|c|c|c|c|c|}
\hline Group/species & Source & SS & DF & MS & $\mathrm{F}$ & $\mathrm{p}$ \\
\hline Wood ants & $\begin{array}{l}\text { Stand } \\
\text { Treatment } \\
\text { Stand } * \text { treatment } \\
\text { N1993 } \\
\text { Error }\end{array}$ & $\begin{array}{l}0.052 \\
0.099 \\
0.477 \\
1.579 \\
1.232\end{array}$ & $\begin{array}{r}2 \\
1 \\
2 \\
1 \\
11\end{array}$ & $\begin{array}{l}0.026 \\
0.099 \\
0.238 \\
1.579 \\
0.112\end{array}$ & $\begin{array}{r}0.231 \\
0.886 \\
2.128 \\
14.097\end{array}$ & $\begin{array}{l}\text { Ns } \\
\text { Ns } \\
\text { Ns } \\
0.003\end{array}$ \\
\hline Carabid beetles & $\begin{array}{l}\text { Stand } \\
\text { Treatment } \\
\text { Stand * treatment } \\
\text { N1993 } \\
\text { Error }\end{array}$ & $\begin{array}{l}0.153 \\
0.658 \\
0.113 \\
0.436 \\
0.568\end{array}$ & $\begin{array}{r}2 \\
1 \\
2 \\
1 \\
11\end{array}$ & $\begin{array}{l}0.076 \\
0.658 \\
0.056 \\
0.436 \\
0.052\end{array}$ & $\begin{array}{r}1.479 \\
12.752 \\
1.091 \\
8.456\end{array}$ & $\begin{array}{l}\text { Ns } \\
0.004 \\
\text { Ns } \\
0.014\end{array}$ \\
\hline C. micropterus & $\begin{array}{l}\text { Stand } \\
\text { Treatment } \\
\text { Stand } * \text { treatment } \\
\text { N1993 } \\
\text { Error }\end{array}$ & $\begin{array}{l}0.030 \\
0.507 \\
0.067 \\
0.471 \\
0.849\end{array}$ & $\begin{array}{r}2 \\
1 \\
2 \\
1 \\
11\end{array}$ & $\begin{array}{l}0.015 \\
0.507 \\
0.034 \\
0.471 \\
0.077\end{array}$ & $\begin{array}{l}0.015 \\
6.561 \\
0.436 \\
6.097\end{array}$ & $\begin{array}{l}\mathrm{Ns} \\
0.026 \\
\mathrm{Ns} \\
0.031\end{array}$ \\
\hline P. oblongopunctatus & $\begin{array}{l}\text { Stand } \\
\text { Treatment } \\
\text { Stand * treatment } \\
\text { N1993 } \\
\text { Error }\end{array}$ & $\begin{array}{l}0.347 \\
0.570 \\
0.348 \\
1.035 \\
0.649\end{array}$ & $\begin{array}{r}2 \\
1 \\
2 \\
1 \\
11\end{array}$ & $\begin{array}{l}0.174 \\
0.570 \\
0.174 \\
1.035 \\
0.059\end{array}$ & $\begin{array}{r}2.947 \\
9.674 \\
2.948 \\
17.562\end{array}$ & $\begin{array}{l}\text { Ns } \\
0.010 \\
\text { Ns } \\
0.002\end{array}$ \\
\hline N. biguttatus & $\begin{array}{l}\text { Stand } \\
\text { Treatment } \\
\text { Stand * treatment } \\
\text { N1993 } \\
\text { Error }\end{array}$ & $\begin{array}{l}0.072 \\
0.149 \\
0.134 \\
1.045 \\
1.140\end{array}$ & $\begin{array}{r}2 \\
1 \\
2 \\
1 \\
11\end{array}$ & $\begin{array}{l}0.036 \\
0.149 \\
0.067 \\
1.045 \\
0.104\end{array}$ & $\begin{array}{r}0.345 \\
1.438 \\
0.645 \\
10.083\end{array}$ & $\begin{array}{l}\mathrm{Ns} \\
\mathrm{Ns} \\
\mathrm{Ns} \\
0.009 .\end{array}$ \\
\hline C. caraboides & $\begin{array}{l}\text { Stand } \\
\text { Treatment } \\
\text { Stand * treatment } \\
\text { N1993 } \\
\text { Error }\end{array}$ & $\begin{array}{l}1.512 \\
0.342 \\
0.334 \\
0.005 \\
0.404\end{array}$ & $\begin{array}{r}2 \\
1 \\
2 \\
1 \\
11\end{array}$ & $\begin{array}{l}0.756 \\
0.342 \\
0.167 \\
0.005 \\
0.037\end{array}$ & $\begin{array}{r}20.569 \\
9.307 \\
4.551 \\
0.127\end{array}$ & $\begin{array}{c}<0.001 \\
0.011 \\
0.036 \\
\mathrm{Ns}\end{array}$ \\
\hline
\end{tabular}


Table 3. The result of the repeated measures ANOVA (F) for Shannon-Wiener and Simpson diversity indices. The Tukey's post-hoc test was done using pooled data 1994-1996 and without covariables. The test indicates which plot type (control, litter) or stands (A, B, C) differed from the others. For example, C>A, B indicates that the sample sizes in stand $\mathrm{C}$ were higher than in stands $\mathrm{A}$ and $\mathrm{B}$ (which were thus similar)

\begin{tabular}{|c|c|c|c|c|c|c|}
\hline $\begin{array}{l}\text { Shannon-Wiener's H' } \\
\text { Source }\end{array}$ & SS & DF & MS & $\mathrm{F}$ & $\mathrm{p}$ & Post-hoc test \\
\hline Treat & 0.002 & 1 & 0.002 & 0.354 & Ns & \\
\hline Stand & 0.025 & 2 & 0.013 & 1.955 & Ns & \\
\hline Treat $*$ Stand & 0.066 & 2 & 0.033 & 5.098 & 0.027 & \\
\hline N1993 & 2.007 & 1 & 2.007 & 310.569 & $<0.001$ & \\
\hline Error & 0.071 & 11 & 0.006 & & & \\
\hline \multicolumn{7}{|l|}{ Simpson's D } \\
\hline & & & & & & \\
\hline Treat & 0.000 & 1 & 0.000 & 0.007 & Ns & \\
\hline Stand & 0.027 & 2 & 0.014 & 8.802 & 0.005 & $C>A, B$ \\
\hline Treat $*$ Stand & 0.017 & 2 & 0.009 & 5.529 & 0.022 & \\
\hline N1993 & 0.620 & 1 & 0.620 & 398.655 & $<0.001$ & \\
\hline Error & 0.017 & 11 & 0.002 & & & \\
\hline
\end{tabular}

most common species increased in the litter plots as compared with the control ones, but 2) we did not detect any litter effects on the number of species or diversity and evenness indices, whereas 3 ) the carabidassemblage structure was affected owing to different response of species to the litter addition. We discuss these findings in relation to species characteristics, habitat and microhabitat variation, and species' interactions below.

\section{Species characteristics explaining the distribution patterns}

Carabids are often non-randomly distributed on the forest floor, although the environment may seem to be homogeneous to the human eye (Grüm 1971, Niemelä et al. 1986, 1992, Luff 1987, Haila et al. 1994b). Carabid populations consist of decision-making individuals (den Boer 1979), which actively select the most favorable microhabitat in their environment (Mossakowski 1979, Niemelä et al. 1992). Humidity, temperature, light, and physical and chemical qualities of soil can have an effect on their distribution patterns (Thiele 1977, Lindroth 1985). Also interspecific interactions such as competition, predation and parasitism can greatly influence the distribution of carabid beetles and food available to them (Sergeeva 1994). However, abiotic factors are probably more important than biotic ones in determining distribution patterns (e.g. Thiele 1964). The higher catches of carabids in the litter plots in our data may be due to several factors. Firstly, carabid individuals may have actively selected this microhabitat, as e.g. Niemelä et al. (1992) have proposed. Alternatively, demographic processes may have differed between the litter and the control plots. The mortality rate may have been lower or the birth rate higher in the litter plots. Additionally, the trapping efficiency may have been different in different plot types (see e.g. Southwood 1978).

Some important characteristics of the eight most common carabid species in Finnish coniferous forests are presented in Table 4. Many species-specific characteristics, such as feeding behavior, may be related to species distribution in association to leaf litter. Carabids are mainly predators, but nearly every species has quite diverse diet consisting of invertebrates, carrions and plant material (Hengeveld 1980a, b, c). Of the two most common forest-carabid species in mature taiga (Niemelä et al. 1988), P. oblongopunctatus is a generalist but $C$. micropterus seems to be strictly carnivorous (Lindroth 1986, see also Hengeveld 1980c). The representatives of genus Amara are plant eaters feeding mainly on seeds but also on other parts of plants (e.g. Lindroth 1986). In contrast, $N$. biguttatus eats mainly springtails (Collembola) (Hengeveld 1980a, b, c, Lindroth 1985), and C. caraboides is specialized on preying upon molluscs (Thiele 1977). The amount of food is one of the most important biotic factors affecting carabid distributions (Thiele 1977, Niemelä 1993a, Sergeeva 1994). In the soil samples taken from the humus layer of our study plots, there were more springtails in the litter than in the control plots, whereas the numbers of mites did not show differences between the plot types (Koivula 1996). Further, the numbers of carabids correlated positively with the numbers of springtails, but not with those of mites. A similar positive correlation between pitfall catches of carabids and springtails was reported by Niemelä et al. (1986).

Despite the higher numbers of potential food items, springtails, the springtail specialist $N$. biguttatus was equally numerous in both plot types. This may indicate that the amount of food is not a crucial factor explaining our results for this species. On the other hand, the 
species may not find the increase of springtail numbers sufficient enough to move to or to survive better in litter plots. Alternatively, this species does not prey upon springtails within the litter layer but instead hunts them on the top of the litter. The increased numbers of springtails were recorded within the humus layer, and we have no data on the springtail numbers from the top of the litter (Koivula 1996). Cychrus caraboides is specialized on preying upon terrestrial land snails (Lindroth 1985). In 1994, the pitfall catches of slugs were significantly higher in the litter than in the control plots (Koivula unpubl.). This may indicate that the litter plots are favorable for terrestrial land snails, too, and further, they might attract $C$. caraboides individuals to the litter plots.

Carabids also differ in their dispersal ability. Longwinged species are usually more successful colonizers (Ranta and As 1982). However, many of the most numerous species, e.g. C. micropterus, $P$. oblongopunctatus and $C$. caraboides, are poor dispersers (den Boer 1977). Notiophilus biguttatus populations may include both long- and short-winged individuals (Lindroth 1985). The most numerous species in our samples are likely to be poor dispersers, with $N$. biguttatus as a possible exception. However, the species that increased in the litter-plot samples were the most common ones. The pool of mature-forest species is rather small (e.g. Niemelä 1993a); thus the colonization of the litter plots by any further species is not likely.

\section{The importance of the physical environment}

Higher beetle catches in the litter-plot samples may be attributable to abiotic factors such as humidity and temperature, and to some physical and chemical properties of the soil which all are important environmental factors for carabid beetles (Thiele 1964, 1977, Lindroth 1985). Leaf-litter material may offer shelter against predators and evaporation. For spiders, leaf-litter envi- ronment has been suggested to offer more stable humidity and temperature conditions, thus providing favorable conditions for reproduction (Uetz 1979, Bultman and Uetz 1982, 1984). This may be the case for carabid beetles as well. In our study, the leaf-litter material was moist even during the driest months in the summer in contrast to very dry moss layer in the control plots (Koivula unpubl.).

Some species may respond negatively to leaf litter. For instance, $N$. biguttatus is sun-loving, day-active species living in quite dry habitats (Lindroth 1985). Although we have no data on the shadiness of the plots, the shadiness may have been a crucial factor for $N$. biguttatus. Indeed, the catches of $N$. biguttatus were at their highest at the well-lit stand B. In contrast, $A$. brunnea and L. terminatus tend to live in microhabitats with much leaf litter (Lindroth 1985, 1986). In a study with only one forest stand, Niemelä et al. (1992) got the highest catches of $C$. micropterus at places with much needle litter. In our data, however, the catches increased in the leaf-litter plots. Thus, the litter itself, or the amount, regardless the quality, might be important for the species. In the same study, the catches of $P$. oblongopunctatus were highest at places with much aspen-leaf litter. However, the catches increased in the litter plots in our study, too. Additionally, the distribution pattern of C. caraboides, which increased in litterplot samples in our study, is affected by the amount of humus and soil moisture (Lindroth 1985, Niemelä et al. 1992). Generally, our results regarding the relationship between forest-floor vegetation and occurrence of these four carabid species support the earlier studies.

Variety of niches may favor a diverse community (Giller 1984). Leaf litter may offer new niches, thus enabling more species to coexist in a given stand. The diversity and evenness indices and species richness, however, did not differ between the leaf-litter and control plots although the overall numbers of carabid individuals in the samples increased after the litter was added. Our results may, however, be attributable to the

Table 4. The eight most common taiga carabid species (according to Niemelä et al. 1988, 1994, 1996) and some of their ecological characteristics. Nomenclature follows Lindroth $(1985,1986)$. Wing length: $\mathrm{B}=$ brachypterous, $\mathrm{M}=$ macropterous Activity: $\mathrm{N}=$ night-active, $\mathrm{D}=$ day-active species. Guild: $\mathrm{I}=$ litter surface, III = within the litter and II = between these two. Overwintering stage: $\mathrm{L}=$ larval, $\mathrm{A}=$ adult. Food preference: $\mathrm{C}=$ carnivorous, $\mathrm{G}=$ generalist, $\mathrm{S}=$ specialist and $\mathrm{P}=$ plant eater Size, wing length, activity and overwintering habits according to Lindroth 1985, 1986. Guild according to Sergeeva 1994. Food preference according to Lindroth 1985, 1986, Hengeveld 1980a, b, c. Habitat preference according to Lindroth 1985, 1986, Niemelä et al. $1988,1992$.

\begin{tabular}{llllllll}
\hline Species & Size $(\mathrm{mm})$ & Wings & Activity & Guild & Winter & Food & Habitat pref. \\
\hline Calathus micropterus (Dft.) & $6.5-8.8$ & B & N & III & L & C & needle litter \\
Pterostichus oblongopunctatus (F.) & $9.5-12.6$ & M* & N (D) & II & A & G & leaf litter \\
Notiophilus biguttatus (F.) & $5-6$ & B & D & III & A & CS & dry \\
Cychrus caraboides L. & $14-19$ & B & N & I & L & GS & humus, moist \\
Carabus glabratus Payk. & $22-30$ & B & D & I & A & G & mosses \\
Amara brunnea (Gyll.) & $5.2-6.8$ & M & N & III & L & P & mosses, leaf litter \\
Carabus hortensis L. & $22-28$ & B & N & I & L & G & humus, dry \\
Leistus terminatus (Hellw. in Pz.) & $6-8$ & B & N & III & L & G & leaf litter \\
\hline
\end{tabular}

* no flight observations (Lindroth 1986). 
rather small pool of carabid species inhabiting mature mesic taiga. Leaf-litter microhabitat seems to be favorable for some species (e.g. C. micropterus, $P$. oblongopunctatus and $C$. caraboides), but not for some others (e.g. N. biguttatus). At a forest-stand level, this probably leads to different aggregation patterns of different carabid species.

\section{Species' interactions}

Interspecific competition may affect carabid distribution patterns, although this may not be important in the entire carabid communities (e.g. Dennison and Hodkinson 1984), and the importance of competition remains largely unclear (Niemelä 1993b, but see Currie et al. 1996). In a forest ecosystem, it has been suggested that only the most numerous species compete (Loreau 1992), but that there are many differences in these species' ecology (e.g. food preferences, phenology) that make interspecific competition unlikely in taiga forests. Niemelä (1993a) also suggested that in a predictably unfavorable habitat, such as taiga forest, the severity might keep the competitors out. In carabids, however, competition at the larval stage may be more important than at the adult stage, and competition could exist between e.g. staphylinid beetles and carabid larvae (e.g. Thiele 1977, Spence 1979). Nevertheless, interspecific competition may be one factor in keeping carabid densities quite low in the taiga forests. Sergeeva (1994) separated three guilds of carabid species living in different layers of litter (Table 4). The increase in the catches of some species (e.g. P. oblongopunctatus, $C$. caraboides and $C$. micropterus) may be due to altered forest-floor structure, i.e. the leaf-litter microenvironment may provide more room in vertical direction for carabid adults and larvae, thus enabling more individuals to live simultaneously in a given microhabitat.

Our RDA analyses (data 1993 and 1993-1996) indicated that also the wood ants have an effect on the carabid catches. There is evidence that $N$. biguttatus copes better in high wood-ant densities than e.g. $P$. oblongopunctatus and $C$. caraboides (Niemelä et al. 1992). Punttila (1994) has suggested that such a difference is likely to be a result from the different susceptibility of night- and day-active carabid species to interference and/or predation caused by the wood ants. The wood ants hunt (mostly) in daytime and may thus find the nightactive species from their resting sites e.g. within the litter. In contrast, the vividly moving, day-active $N$. biguttatus should be more capable of avoiding the wood-ant predation and be less dis- turbed by the wood ants than the night-active species.

\section{The levels of variation and conclusions}

Our data revealed two levels of variation. First, both floristic and, especially, carabid-assemblage variation was considerable among the stands. Further, for carabids this variation was consistent throughout the study years. Second, a similar kind of variation was found also at the smaller scale, among the plots within the stands, in both vegetation and carabid data, and this variation was again consistent throughout the study years in the carabid data. The effect of the experimental litter addition was detectable in the carabid assemblage, although not similarly in the different forest stands or among the species. Our data suggest that the magnitude of the litter-addition effect may depend on the fertility of the stand in the first place. The litter effect was largest in the least fertile stand $\mathrm{B}$, and weakest in the most fertile stand $\mathrm{C}$. Thus, in forests with poor soil and humus layer, the scattered deciduous trees are likely to be especially important for forest-floor fauna. The existence of such a phenomenon, however, awaits further research with larger data set. If litter aggregations have a positive effect on common, generalized carabid species, it is likely that they favor scarcer species, too. The importance of microhabitat differences, such as litter depth, was found to be important in explaining carabid abundance in a field experiment in Canada (Niemelä et al. 1997). Thus, studies on litter effects on other beetle groups, spiders and molluscs, would be fruitful as well as studying the litter quality in more detail. Such data are needed in order to draw more general conclusions on the importance of deciduous trees for forest-floor invertebrates. Also further experimental work on the effect on the litter quality, e.g. different fertilizing value and $\mathrm{pH}$ of various types of litter and artificial litter without any fertilizing value, providing only shelter, might shed some light on the reasons for the aggregated distribution patterns of carabids.

The removal of aspens from managed forests has caused population declines of e.g. many insect species (Siitonen and Martikainen 1994), epiphytic lichens (Kuusinen 1994) and polypores (Kotiranta and Niemelä 1996) living on aspen trunks. Our results indicated that also the litter of aspen has a positive effect on invertebrate numbers, and this may further be reflected in the aggregated distribution patterns on the forest-stand level. Thus, we warmly recommend forest owners and managers to leave more deciduous trees in their forests, and favor mixed forests mimicking natural tree-species composition instead of monocultures of conifers. 
Acknowledgements - Several colleagues and others helped in the field: S. Finnilä, H. Kinnunen, H. Koivula, R. Lumiaro, M. Nylund, T. Seppä, N. Wahlberg and Y. Haila's hometroops. We thank R. Forsman, T. Hyvönen, S. Lehvävirta, T. Seppä, L. Sundström and M. Ost, H. Rita and J. Kouki for constructive comments. We also thank the staff of Seitseminen National Park, Satakunta Environmental Research Center of University of Turku, and Häme Park Area of Finnish Forest and Park Service. The Academy of Finland financed this work (project 10134485).

\section{References}

Ahti, T., Hämet-Ahti, L. and Jalas, J. 1968. Vegetation zones and their sections in northwestern Europe. - Ann. Bot. Fenn. 5: 169-211.

Bird, G. A. and Chatarpaul, L. 1988. Effect of forest harvest on decomposition and colonization of maple leaf litter by soil microarthropods. - Can. J. Soil. 68: 29-40.

Boag, D. A. 1985. Microdistribution of three genera of small terrestrial snails (Sylommatophora: Pulmonata). - Can. J. Zool. 63: 1089-1095.

Bossenbroek, P. H. et al. 1977. The significance of plant growth-forms as a "shelter" for terrestrial animals. - J. Zool. (Lond.) 182: 1-6.

Bultman, T. L. and Uetz, G. W. 1982. Abundance and community structure of forest floor spiders following litter manipulation. - Oecologia 55: 34-41.

Bultman, T. L. and Uetz, G. W. 1984. Effect of structure and nutritional quality of litter on abundances of litter-dwelling arthropods. - Am. Midl. Nat. 111: 165-172.

Byers, J. A. 1984. Electronic multiprobe thermometer and multiplexer for recording temperatures of microenvironments in the forest litter habitat of bark beetles (Coleoptera: Scolytidae). - Environ. Entomol. 13: 863867.

Cajander, A. K. 1949. Forest types and their significance. Acta For. Fenn. 56: 1-71.

Currie, C. R., Spence, J. R. and Niemelä, J. 1996. Competition, cannibalism and intraguild predation among ground beetles (Coleoptera: Carabidae): a laboratory study. Coleopt. Bull. 50: 135-148.

den Boer, P. J. 1977. Dispersal power and survival. Carabids in a cultivated countryside. - Misc. Pap., Landb. Hogeschool Wageningen 14.

den Boer, P. J. 1979. Populations of carabid beetles and individual behaviour: general aspects. - In: den Boer, P. J., Thiele, H. U. and Weber, F. (eds), On the evolution of behaviour in carabid beetles. Misc. Pap. 18, H. Veenman and Zonen B. V., Wageningen, Netherlands, pp. 145-150.

den Boer, P. J. 1990. Density limits and survival of local populations in 64 carabid species with different powers of dispersal. - J. Evol. Ecol. 3: 19-48.

Dennison, D. F. and Hodkinson, I. D. 1984. Structure of the predatory beetle community in a woodland soil ecosystem. V. Summary and conclusions. - Pedobiologia 26: 171-177.

Esseen, P.-E. et al. 1997. Boreal forests. - Ecol. Bull. 46: 16-47.

Facelli, J. M. and Pickett, S. T. A. 1991. Plant litter: light interception and effects on an old-field plant community. Ecology 72: 1024-1031.

Giller, P. S. 1984. Community structure and the niche. Chapman and Hall.

Grüm, L. 1971. Remarks on the differentiation in Carabidae mobility. - Ekol. Pol. 19: 47-56.

Haila, Y. and Kouki, J. 1994. The phenomenon of biodiversity in conservation biology. - Ann. Zool. Fenn. 31: 5-18.

Haila, Y. et al. 1994a. Forestry and the boreal fauna: matching management with natural forest dynamics. - Ann. Zool. Fenn. 31: 187-202.
Haila, Y. et al. 1994b. Metsätalouden ekologiset vaikutukset boreaalisessa havumetsässä: tutkimustuloksista käytännön suosituksiin. - In: Haila, Y., Niemelä, P. and Kouki, J. (eds), Effects of management on the ecological diversity of boreal forests. Metsäntutkimuslaitoksen tiedonantoja 482, Finnish For. Res. Inst. Finland, pp. 7-17, in Finnish.

Hansson, L. 1992. Landscape ecology of boreal forests. Trends Ecol. Evol. 7: 299-302.

Hengeveld, R. 1980a. Qualitative and quantitative aspects of the food of ground beetles (Coleoptera: Carabidae): a review. - Neth. J. Zool. 30: 555-563.

Hengeveld, R. 1980b. Polyphagy, oligophagy and food specialization in ground beetles (Coleoptera, Carabidae). - Neth. J. Zool. 30: 564-584.

Hengeveld, R. 1980c. Food specialization in ground beetles: an ecological or a phylogenetic process? (Coleoptera: Carabidae). - Neth. J. Zool. 30: 585-594.

Jongman, R. H. G., ter Braak, C. J. F. and van Tongeren, O. F. R. (eds) 1995. Data analysis in community and landscape ecology. - Cambridge Univ. Press.

Kärkkäinen, M. 1981. Happa- ja poppelilajien (Populus) käyttö. - Silva Fennica 15: 156-179, in Finnish.

Koivula, M. 1996. Lehtikarikkeen lisäämisen vaikutus MTmetsän maakiitäjäisten runsauteen. - M.Sc. thesis, Dept of Ecology and Systematics, Univ. of Helsinki, in Finnish.

Kotiranta, H. and Niemelä, T. 1996. Threatened polypores in Finland. 2nd revised ed. - Finnish Environ. Inst., Helsinki, in Finnish with English summary.

Krebs, C. J. 1989. Ecological methodology. - Harper and Row.

Kuusinen, M. 1994. Epiphytic lichen flora and diversity on Populus tremula in old-growth and managed forests of southern and middle boreal Finland. - Ann. Bot. Fenn. 31: $245-260$.

Langor, D. et al. 1994. Insect biodiversity in the boreal forests of Alberta, Canada. - In: Haila, Y., Niemelä, P. and Kouki, J. (eds), Effects of management on the ecological diversity of boreal forests. Metsäntutkimuslaitoksen tiedonantoja 482: 25-31. Finnish For. Res. Inst., Finland, in Finnish.

Lindroth, C. H. 1985. The Carabidae (Coleoptera) of Fennoscandia and Denmark. Vol. 15, part 1. - Fauna Entomol. Skandinavica, Leiden, Copenhagen.

Lindroth, C. H. 1986. The Carabidae (Coleoptera) of Fennoscandia and Denmark. Vol. 15, part 2. - Fauna Entomol. Skandinavica, Leiden, Copenhagen.

Loreau, M. 1992. Species abundance patterns and the structure of ground-beetle communities. - Ann. Zool. Fenn. 28: 49-56.

Luff, M. L. 1987. Biology of polyphagous ground beetles in agriculture. - Agricult. Zool. Rev. 2: 237-278.

Martikainen, P. et al. 1994. The effect of forest management on the distribution of saproxylic beetles in Finnish and Russian Karelia. - In: Haila, Y., Niemelä, P. and Kouki, J. (eds), Effects of management on the ecological diversity of boreal forests. Metsäntutkimuslaitoksen tiedonantoja 482, Finnish For. Res. Inst., Finland, pp. 97-104, in Finnish with English summary.

Mascanzoni, D. and Wallin, H. 1986. The harmonic radar: a new method of tracing insects in the field. - Ecol. Entomol. 11: 387-390.

Mossakowski, D. 1979. Evolution of habitat preference illustrated by the phylogeny of Chrysocarabus. - In: den Boer, P. J., Thiele, H. U. and Weber, F. (eds), On the evolution of behaviour in carabid beetles. Misc. pap. 18, H. Veenman and Zonen B. V., Wageningen, Netherlands, pp. 103-112.

Niemelä, J. 1990. Spatial distribution of carabid beetles in the southern Finnish taiga: a question of scale. - In: Stork, N. (ed.), Ground beetles: their role in ecological and environmental studies. Intercept Publ., Andover, England, pp. $143-155$.

Niemelä, J. 1993a. Mystery of the missing species: speciesabundance distribution of boreal ground beetles. - Ann. Zool. Fenn. 30: 169-172. 
Niemelä, J. 1993b. Interspecific competition in ground-beetle assemblages (Carabidae): what have we learned? - Oikos 66: $325-335$.

Niemelä, J. 1997. Invertebrates and boreal forest management. - Conserv. Biol. 11: 601-610.

Niemelä, J., Haila, Y. and Ranta, E. 1986. Spatial heterogeneity of carabid beetle dispersion in uniform forests on the Aland Islands, SW Finland. - Ann. Zool. Fenn. 23: 289 296.

Niemelä, J., Haila, Y. and Halme, E. 1988. Carabid beetles on isolated Baltic islands and on the adjacent Aland mainland: variation in colonization success. - Ann. Zool. Fenn. 25: $133-143$.

Niemelä, J. et al. 1992. Small-scale heterogeneity in the spatial distribution of carabid beetles in the southern Finnish taiga. - J. Biogeogr. 19: 173-181.

Niemelä, J., Tukia, H. and Halme, E. 1994. Patterns of carabid diversity in Finnish mature taiga. - Ann. Zool. Fenn. 31: 123-129.

Niemelä, J., Haila, Y. and Punttila, P. 1996. The importance of small-scale heterogeneity in boreal forests: variation in diversity in forest-floor invertebrates across the succession gradient. - Ecography 19: 352-368.

Niemelä, J., Spence, J. R. and Cárcamo, H. 1997. Establishment and interactions of carabid populations: an experiment with native and introduced species. - Ecography 20: $643-652$.

Nuorteva, M. 1987. Förändringar i insektsfaunan i Finlands skogar. - Entomol. Medd. 55: 125-128, in Swedish.

Punttila, P. 1994. Keomuurahaiset ja niveljalkaisyhteisöjen rakenne. - In: Haila, Y., Niemelä, P. and Kouki, J. (eds), Effects of management on the ecological diversity of boreal forests. Metsäntutkimuslaitoksen tiedonantoja 482: 47-58. Finnish For. Res. Inst., Finland, in Finnish.

Ranta, E. and As, S. 1982. Non-random colonization of habitat islands by carabid beetles. - Ann. Zool. Fenn. 19: $175-181$.

Reddy, M. V. 1984. Seasonal fluctuation of different edaphic microarthropod population densities in relation to soil moisture and temperature in a pine, Pinus kesiya Royle plantation ecosystem. - Int. J. Biometeorol. 28: 55-59.
Seastedt, T. R. et al. 1983. A two-year study of leaf litter decomposition as related to macroclimatic factors and microarthropod abundance in the southern Appalachians. - Holarct. Ecol. 6: 11-16.

Sergeeva, T. K. 1994. Seasonal dynamics of interspecific trophic relations in a carabid beetle assemblage. - In: Desender K. et al. (eds), Carabid beetles: ecology and evolution. Kluwer, pp. 367-370.

Siitonen, J. and Martikainen, P. 1994. Occurrence of rare and threatened insects living on decaying Populus tremula: a comparison between Finnish and Russian Karelia. Scand. J. For. Res. 9: 185-191.

Simberloff, D. 1978. Use of rarefaction and related methods in ecology. - In: Dickson, K. L., Garins, J. Jr and Livingston, R. J. (eds), Biological data in water pollution assessment: quantitative and statistical analysis. Am. Soc. for Testing and Materials STP 652: $150-165$

Southwood, T. R. E. 1978. Ecological methods. 2nd ed. Chapman and Hall.

Spence, J. R. 1979. Riparian carabid guilds-a spontaneous question generator. - In: Erwin, T. L., Ball, G. E. and Whitehead, D. R. (eds), Carabid beetles: their evolution, natural history, and classification. Junk, Den Haag, pp. $525-537$.

ter Braak, C. J. F. 1987. CANOCO - A FORTRAN program for canonical community ordination by [partial] [detrended] [canonical] correspondence analysis, principal components analysis and redundancy analysis (ver. 2.0). TNO Inst. of Applied Computer Sci., Statistics Dept Wageningen, Wageningen, The Netherlands.

Thiele, H.-U. 1964. Experimentelle Untersuchungen über die Ursachen der Biotopbindnung bei Carabiden. - Z. Morphol. Ökol. Tiere 58: 355-372.

Thiele, H. -U. 1977. Carabid beetles in their environments. Springer

Uetz, G. W. 1979. The influence of variation in litter habitats on spider communities: - Oecologia 40: 29-42.

Underwood, A. J. 1991. Beyond BACI: experimental designs for detecting human environmental impacts on temporal variations in natural populations. - Aust. J. Mar. Freshwater Res. 42: 569-587. 